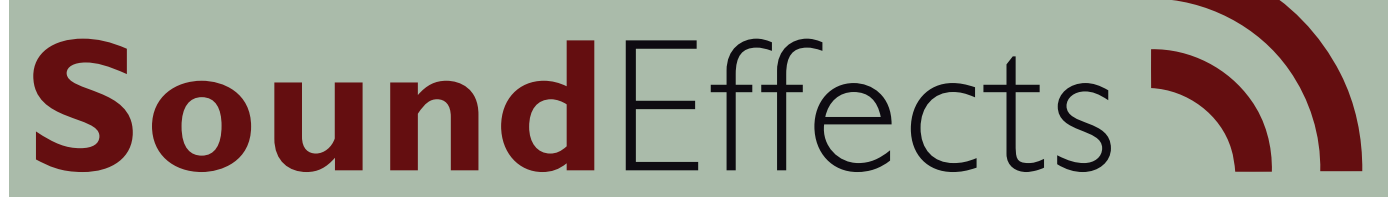

An Interdisciplinary Journal of Sound and Sound Experience

\title{
The Bloomsbury Handbook of Sound Art. Edited by Sanne Krogh Groth and Holger Schulze. Bloomsbury, 2020.
}

\section{Reviewed by Vadim Keylin}


What is sound art? Some fifty years after this combination of words was first documented, the question remains the subject of heated discussions - battles even - among both practitioners and theorists. It is no wonder then that the newest compendium on the art form - The Bloomsbury Handbook of Sound Art, edited by Sanne Krogh Groth and Holger Schulze - opens with a brief account of those debates in order to situate the book's own position on the battlefield. What is at stake, however, is more than a matter of simple definition.

Ostensibly, the editors position the Handbook somewhere between the academically narrow treatment of sound art in German theory, spearheaded by musicologist Helga de la Motte-Haber, and the recent attempts to avoid the definition conundrum altogether, exemplified e.g. by the Routledge Companion to Sounding Art. But already in its choice of refence points, the Handbook's revisionist drive becomes apparent. It has to be commended for being by and large the first major Anglophone publication to acknowledge the contribution of the German theory to the sound art discourse - though unsurprisingly so, given the editors' academic background in German and Danish academia, respectively.

While celebrating de la Motte-Haber as a woman scholar originating an important and influential theory in a male-dominated field, Krogh Groth and Schulze also identify major limitations in her approach: 'Euro- and Germano-centrism, ignoring the vernacular sound practices of popular culture, overly focusing on the psychology of perception, and the depoliticization of sound art'. This dialectic gives direction to the rest of the Handbook - on the one hand, it operates in dialogue with the German scholarship; on the other hand, it aims to expand and redefine the narrative of sound art.

The most evident expansion here is the literal - geographic - one. The Handbook engages with the decolonial turn in recent sound studies, particularly in its second part 'Journeys across the grid' (but also, on a more theoretical level, in a number of chapters assigned to different thematic sections). Here, one can find Krogh Groth's and Bob Edrian's accounts of Indonesian sound art, from outsider and insider perspectives, respectively, Søren Møller Sørensen's sketch of the Cairo scene, and Cedrik Fermont and Dimitri della Faille's overview of sound art practices in East and Southeast Asia.

While addressing non-Western sonic practices as a necessary part of the sound art discourse is an important and welcome gesture that certainly enriches the Handbook, two issues trouble it. First, many of the practices discussed suspiciously resemble conventional music - authors of some chapters even explicitly profess to including certain forms of music in their understanding of sound art. On its own, this is not a problem, my concern is not with the purity of sound art. But the necessity of such inclusions raises the question of whether the category of sound art, 
defined as it is against the background of Western art music, is at all applicable to non-Western sonic practices rooted in their own cultural contexts and traditions. Krogh Groth's account of Javanese artists' performances at Transmediale ponders how transplanting them from their original situated contexts into the black box of a European festival potentially impoverishes the aesthetic experience for the listener. One has to wonder whether attending to non-Western practices from the perspecitve of (Western) sound art discourse can have the same effect. Or even if it is a colonising gesture itself - something that, as Edrian discusses, was indeed a concern for the Indonesian art scene. To their credit, the authors of the section do acknowledge this problem, even if it is not dealt with at length.

The second issue - which somewhat exacerbates the first - is that decolonial intentions run contrary to the predominantly white and Western academic authorship of the section and the Handbook as a whole. This is somewhat ameliorated, however, by the inclusion of a large number of artist statements and interviews, whose authorship is more diverse. Making them a significant part of the book acknowledges the important role of artistic research and practice in driving the sound art discourse forward (after all, a significant number of theorists working in the field are practicing artists as well). But it is also a clever way to overcome the somewhat limited pool of researchers working on the topic.

The Handbook's decolonial aspirations are one of the ways it addresses the challenge of critical theory and critical art practices, which ostensibly has been largely ignored in sound art circles until recently. Chapters authored by Cathy Lane, Sandra Kazlauskaite, Elen Flügge, Alastair Cameron and Eleni Ikoniadou, and others engage directly with the themes of gender, race, coloniality, and institutional critique. Refusing to side with the critics of sound art as apolitical and thus hopelessly irrelevant, the Handbook instead addresses these themes from a uniquely sonic perspective.

For example, Sharon Renee Stewart's chapter explores sound artworks that operate as hacks - subversive performative gestures that transform established cultural phenomena from the inside. While her case studies inlcude the more conventionally activist actions of Pussy Riot and Goodiepal, she also discusses the political and communal potentials of Pauline Oliveros' introspective practices of sonic meditations and Deep Listening. Thus, sound art reveals that political issues 'are not just to be pointed out, discussed or problematized, but they can also be engaged with-through listening, through sound making, through music making' which creates 'new models for being together in the sonic commons'.

Examples of such new models are offered in the essays by artist-researchers Jeremy Woodruff and Pedro Vieira de Oliveira. Woodruff calls for a sound practice that would transcend the purely aesthetic considerations and engage with social relationships that the artwork is embedded in. However, instead of steering the 
community towards a pre-defined outcome, he suggests '[repurposing] the artistic process toward cooperation', which would make new emergent socialities possible.

Vieira de Oliveira's project of decolonial 'aesthetico-relational sound art' shares a similar sensibility - that the political in sound art should operate through the horizontal engagement of the listener rather than through top-down didactic gestures of the artists. He calls for a move away from the universalising primacy of sound and listening that Western sound studies imply and towards treating the listener as always situated (racialised, gendered) and sound, as a process of relating.

Putting a uniquely sonic spin on the politics of art is one of most important contributions of the Handbook. It is also characteristic of its epistemological approach articulated in the volume's introduction and expanded upon in its penultimate part: thinking with and through sound. Harkening back to Kodwo Eschun's Adventures in Sonic Fiction, widely cited throughout the Handbook's chapters, the idea of sonic thinking is positioned as an alternative to the dry abstractions of Theory with a capital ' $T$ '. In both Vieira de Oliveira's and, later on, Macon Holt's chapters, an idea is explicitly voiced that the materiality of sound, which sound art is ostensibly preoccupied with, is not mutually exclusive, nor opposed to referentiality and meaningmaking. On the contrary, in sonic thinking the two are inseparable, emphasising the experiential and situated knowledges. This is evident, for example, in Anette Vandsø's chapter on ecological sound art. Investigating the aesthetic and political entanglements of documentary sonic practices such as field recording, Vands $\varnothing$ shows how this material-discursive duality transforms ecological issues from mere facts to 'a matter of concern'.

Furthermore, the Handbook addresses not only sonic thinking, but also sonic doing. Quite a few of the chapters deal with the performativity of voice in sound art. For example, Stina Marie Hasse Jørgensen analyses how vocality in performance art subverts the ostensible message, revealing the dystopian in the utopian and the other way around. Cathy Lane's chapter investigates the prominence of voice and spoken word in the works of women sound artists, showing how the gendered corporeality of voice articulates the tabooed presence of the female body.

Importantly, the discussion of sonic doing in the Handbook is not limited to voice. The volume's last section is dedicated to the often-neglected genre of sound art that is instrument building and sound sculpture. The section succinctly addresses the duality of the notion of an instrument as belonging to both musical and scientific contexts. Sanne Krogh Groth and Ulrik Schmidt discuss how instrumental reworkings challenge the ontology of a musical instrument through exposing and subverting the conventions of musical practice. On the other hand, Chris Salter and Alexandre Saunier's chapter attends to the practices of instrument making and remaking through the lenses of technoscience and its influence on artistic production. In acknowledging the performative and expressive aspects of sound and 
attending to both vocal and instrumental ways of soundmaking, the Handbook takes an important and urgent step towards decentring the listening-focused approaches that have long dominated sound art scholarship.

Overall, The Bloomsbury Handbook of Sound Art is an innovative, comprehensive and timely volume that I cannot recommend enough. If I have a small criticism to end on, it is that in its revisionist drive, it might put a bit too much effort into avoiding the conventional theories and histories of sound art. However, unlike the older, established art forms such as music or visual art, sound art's discourse is not a hegemonic one, at least not just yet. It is all too easily erased from the grand narrative of art history - something that has already largely happened with sound sculpture, a practice that went big in the 1970s, but had all but disappeared from art history books by the 2000s. With that in mind, it is perhaps best to approach the Handbook with a view of its professed jumping-off point - the 1999 volume Klangkunst: Tönende Objekte und klingende Räume, which unfortunately remains untranslated into English. 